\title{
Fractured clasts in the Mt Currie Conglomerate at Kata Tjuta (Central Australia): evidence of Early Cambrian earthquakes?
}

\author{
Antek K. Tokarski ${ }^{1}$, Piotr J. Strzelecki ${ }^{2}$ \\ ${ }^{1}$ Polish Academy of Sciences, Institute of Geological Sciences, Research Centre in Kraków; ul. Senacka 1, 31-002 Krakow, \\ Poland; e-mail:ndtokars@cyf-kr.edu.pl \\ ${ }^{2}$ AGH University of Science and Technology, Faculty of Geology, Geophysics and Environmental Protection; \\ al. A. Mickiewicza 30,30-059 Krakow, Poland; e-mail:piotrjanstrzelecki@gmail.com; ORCID ID: 0000-0003-0102-0719
}

(C) 2020 Authors. This is an open access publication, which can be used, distributed and reproduced in any medium according to the Creative Commons CC-BY 4.0 License requiring that the original work has been properly cited.

Received: 25 February 2020; accepted: 23 March 2020; first published online: 18 April 2020

\begin{abstract}
Lower Cambrian Mt Currie conglomerate at Kata Tjuta bornhardts (Central Australia) bears numerous fractured clasts. Clast-cutting fractures are restricted to particular clasts, the matrix of the conglomerate is not fractured. The fractures are tectonic joints of two sets. The joints were formed due to either seismic or aseismic deformation. In the former case, the fractures may result from Early Paleozoic earthquakes.
\end{abstract}

Keywords: fractured clasts, earthquakes, Kata Tjuta, Australia

\section{INTRODUCTION}

In this short contribution, we propose a new interpretation of the origin of clast-cutting fractures in the Mt Currie Conglomerate. This Lower Cambrian conglomerate is a synorogenic fluvial deposit related to the intraplate orogenesis i.e. Petermann Orogeny (570-530 Ma). The thickness of the conglomerate is estimated at 1,590 to 6,100 m (Young et al. 2002 and references therein). The matrix of this poorly sorted conglomerate is siliceous and lacks feldspar (Twidale 2010). The clasts in the conglomerate are composed largely of sandstone, granite, rhyolite and basalt (Young et al. 2002, Nieć et al. 2016). The subangular to well-rounded clasts range in size from pebbles to boulders $(5-25 \mathrm{~cm})$. In some places, numerous clasts are fractured (Twidale 2010). The Mt Currie Conglomerate is well exposed at Kata Tjuta bornhardts in the heart of Australia, SW from Alice Springs (Fig. 1).
Clast-cutting fractures in gravels and conglomerates are largely tectonic joints (Ramsay 1964, Eildelman \& Reches 1992). Moreover, it has been demonstrated that fractured clasts: (1) can be useful for fault kinematic analysis (e.g. Ramsay 1962, 1964, Bradley \& Bradley 1986, Kübler 2013, Kübler et al. 2018) and regional stress reconstructions (e.g. Montes et al. 2005, Meyer at al. 2006, Cuong et al. 2013, Tokarski et al. 2016, Mondal \& Acharyya 2018, Acharyya \& Mondal 2019, Phan et al. 2019) and (2), can be used as fault timing indicators (Tanner 1976, Little 1995, Dor et al. 2006).

\section{FRACTURED CLASTS AT KATA TJUTA}

Numerous fractured clasts within the Mt Currie Conglomerate (Fig. 2A, B) were observed during a short visit to Kata Tjuta in October 2016. The clast cutting fractures are restricted to particular clasts, while the matrix of the conglomerate is not 
fractured (Fig. 2C-F). The traces of the fractures are rectilinear and the fractures belong to two sets. Some clasts are cut by several fractures (Fig. 2E). Most of the fractures are localized whereas some distributed (e.g. Fig. 2E). Discussed fractures are subperpendicular to Kata Tjuta slopes in distinction to slope parallel clast-cutting fractures resulting from weathering (Twidale 2010).
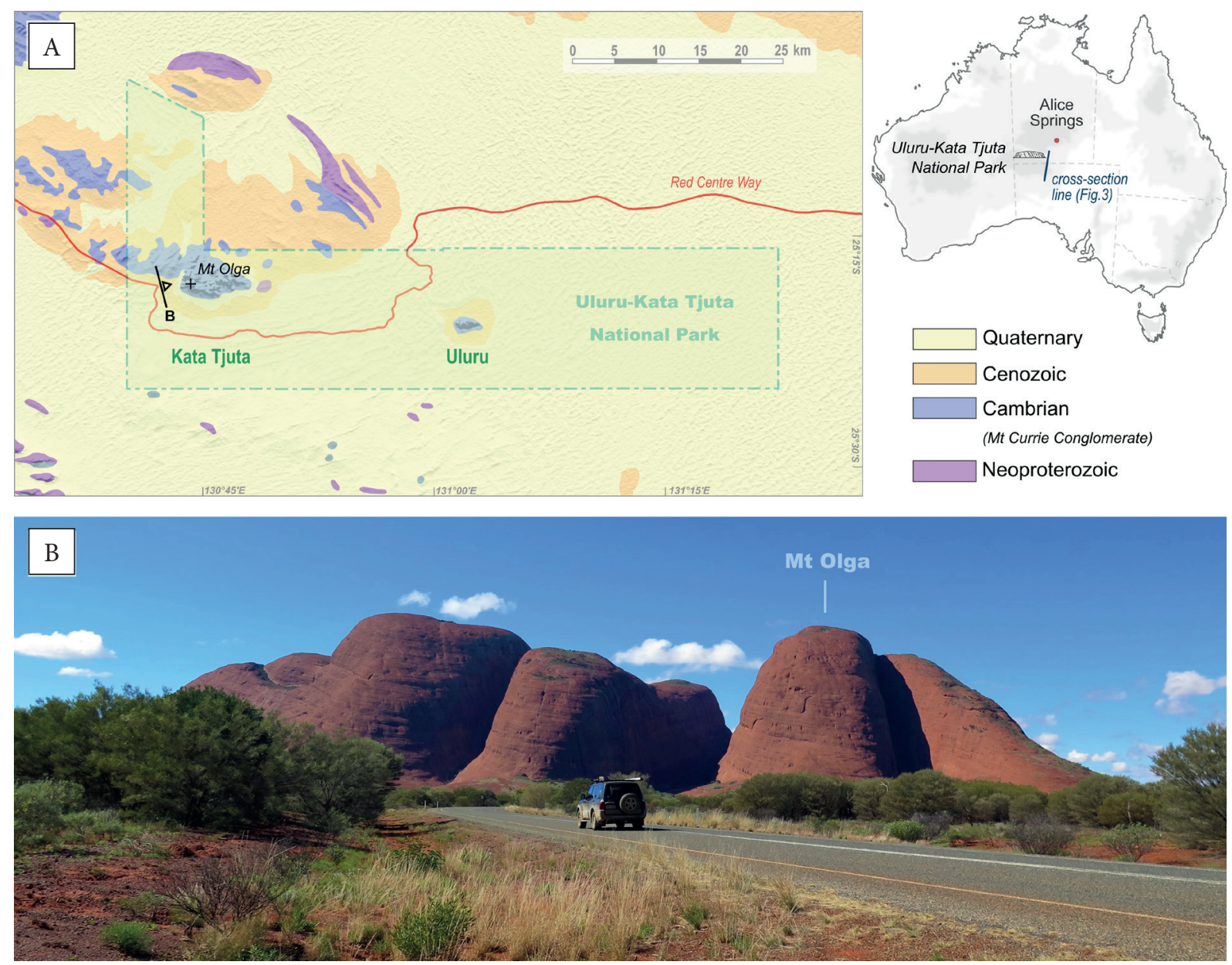

Fig. 1. Kata Tjuta bornhardts: A) location and geology (geology after Raymond et al. 2012); B) view from the WSW, the highest of the domes, Mt. Olga, stands about 1,069 m a.s.l., and some $600 \mathrm{~m}$ above the surrounding plains

\section{ORIGIN OF CLASTS FRACTURING}

To the best of our knowledge, the first observations on fractured clasts were made by Trevelyan (1845). However, the first detailed analysis of clast-cutting fractures was only undertaken over a century later (Kupsch 1955, Ramsay 1962, 1964). Later on, fractured clasts in conglomerates and gravels have been studied in numerous areas and in very different geological settings, ranging from Archaean conglomerate (Acharyya \& Mondal 2019) to Quaternary fluvial gravel (e.g. Phan et al. 2019). The outcome of these studies show that clast-cutting fractures can result from: (1) glacitectonic (e.g. Kupsch 1955) or frost-related cracking, (2) impact-related shocks (Ernston et al. 2001), (3) impact from colliding clasts (e.g. Jerzykiewicz \& Van Helden 1984), (4) aseismic tectonic deformation (Eidelman \& Reches 1992) and, (5) seismic tectonic deformation (e.g. Kübler et al. 2018). 

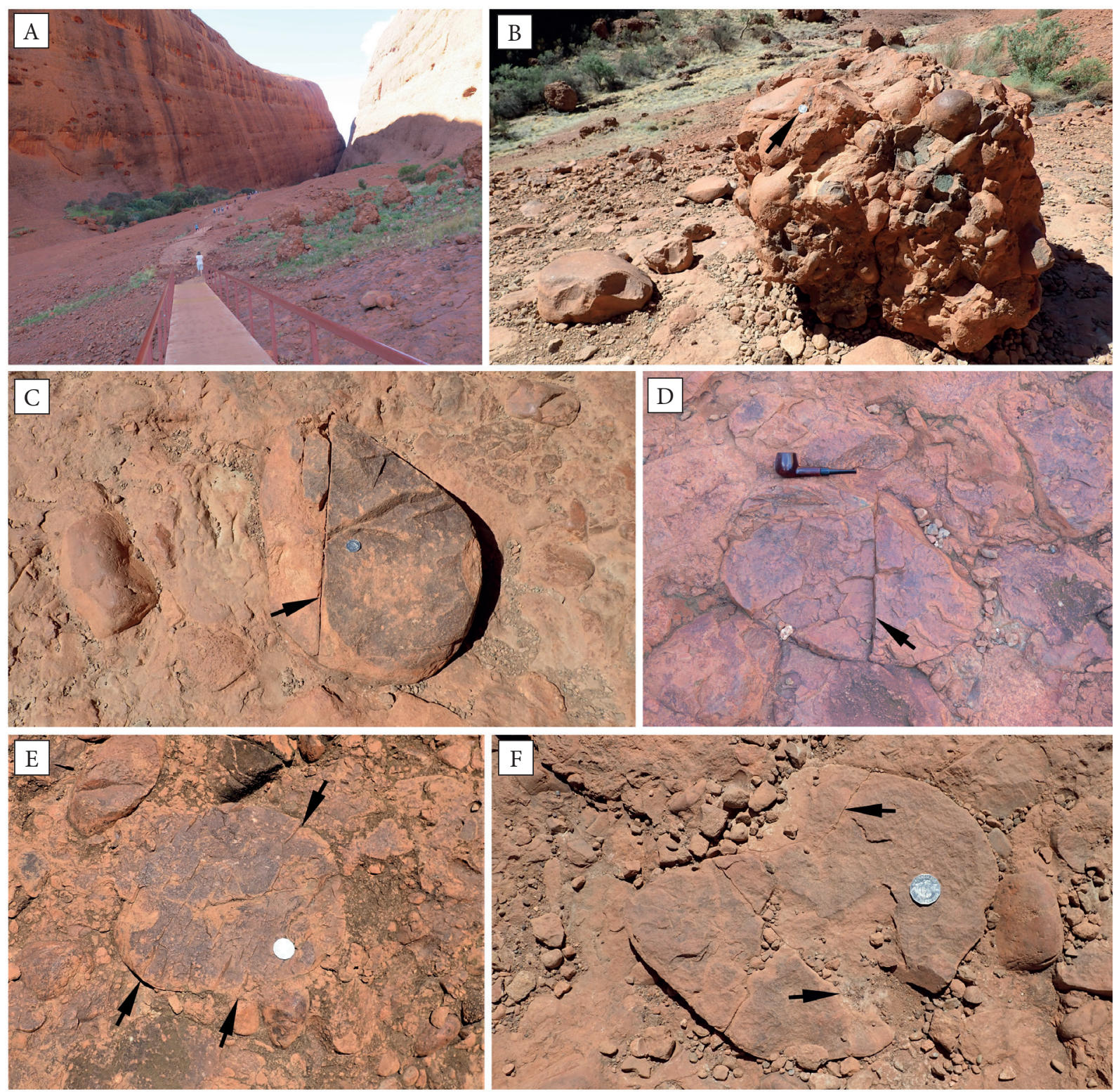

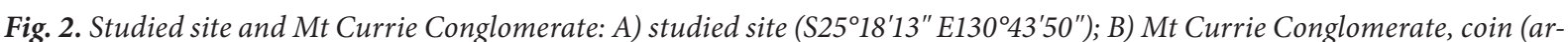
rowed) is $32 \mathrm{~mm}$ in diameter; C), D) clasts cut by single fractures; E) clasts cut by several fractures of single set; F) clast cut by fractures of two sets; all fractures arrowed; coin in B-F (arrowed at B) is $32 \mathrm{~mm}$ in diameter; pipe in D is $12 \mathrm{~cm}$ long

\section{EVIDENCE OF EARLY CAMBRIAN EARTQUAKES}

As already mentioned, clasts cutting fractures in the Mt Currie conglomerate are restricted to particular clasts, while the matrix of the conglomerate is not fractured. It follows, therefore, that the fractures are early features formed when the matrix of the conglomerate was still poorly indurated. Therefore, a glacitectonic or frost-related origin of the fractures is precluded as the study area was neither glaciated nor exposed to periglacial conditions during the deposition of the host conglomerate. Moreover, an impact origin of the fractures can also be ruled out as no radial and/or concentric fractures were observed. It follows, therefore, that the clast-cutting fractures in Mt Currie Conglomerate largely result from tectonic deformation. The synorogenic (Petermann Orogeny) origin of the Mt Currie Conglomerate confirms 
the above conclusion. Moreover, the synorogenic age of the conglomerate favours a seismic (earthquake-related) origin of the discussed clast-cutting fractures. It is also noteworthy that the Kata Tjuta is localized directly at the front of the Petermann Orogen and its deep-seated fault system
(Fig. 3). At the time of the orogenesis, the proximity of the Kata Tjuta localization to the faults may have amplified the impact of earthquake-related deformation. Nevertheless, further field study is necessary to resolve the seismic or aseismic nature of the deformation.

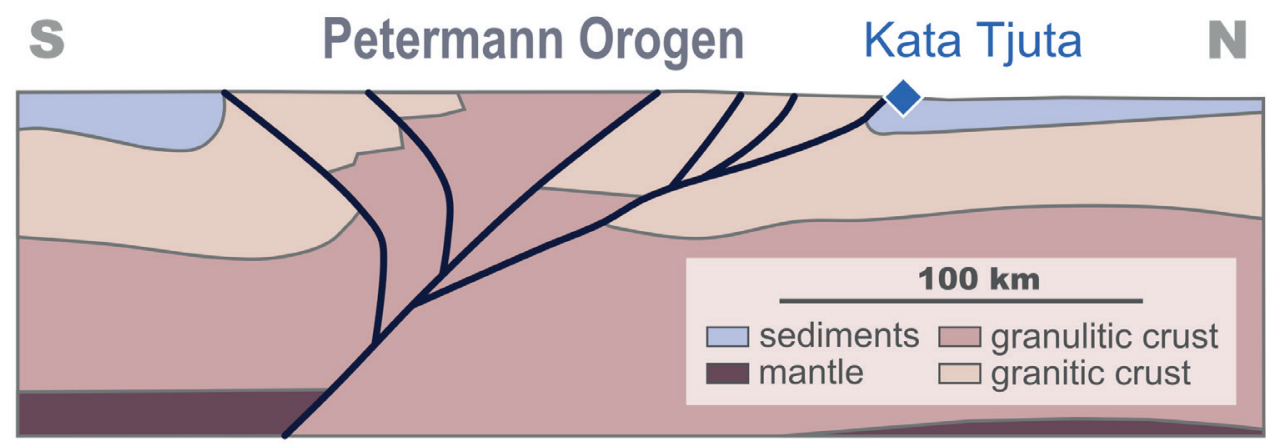

Fig. 3. Position of the Kata Tjuta with respect to the Petermann Orogen and its fault system. Cross-section modified from Sandiford et al. (2001); cross-section line marked on Figure 1

\section{CONCLUSION}

Fractured clasts in the Mt Currie Conglomerate result from tectonic deformation, possibly related to Early Cambrian earthquakes occurring during the Petermann orogenesis in central Australia.

We would like to express our gratitude to Jarek Tyszka for the photos presented on Figure 2B, C, E, $F$ and to Igor Niezgodzki for his technical help.

\section{REFERENCES}

Acharyya S.S. \& Mondal T.K., 2019. Stress enhanced tensile fractures in elliptical clast in conglomerate. Journal of Structural Geology, 122, 81-88.

Bradley D.C. \& Bradley L.M., 1986. Teconic significance of the Carboniferous Big Pond Basin, Cape Breton Island, Nova Scotia. Canadian Journal of Earth Sciences, 23, 2000-2011.

Cuong N.Q., Tokarski A.K., Świerczewska A., Zuchiewicz W.A. \& Yem N.T., 2013. Late Tertiary tectonics of the Red River Fault Zone: Structural evolution of sedimentary rocks. Journal of Geodynamics, 69, 31-53.

Dor O., Rockwell T.K. \& Ben-Zion Y., 2006. Geological observations of damage asymmetry in the structure of the San Jacinto, San Andreas and punchbowl faults in Southern California: possible indicator for preferred rupture propagation direction. Pure and Applied Geophysics, 163, 301-349.
Eildelman A. \& Reches Z., 1992. Fractured pebbles - a new stress indicator. Geology, 20, 307-310.

Ernston K., Rampino M. R. \& Hiltl M., 2001. Cratered cobbles in Triassic Bundsanstein conglomerates in North Eastern Spain: An indicator of shock deformation in the vicinity of large impacts. Geology, 29, 11-14.

Jerzykiewicz T. \& Van Helden D.R., 1984. Preliminary observations on pock Marks and fractured Peebles in the Upper Cretaceous and Paleocene of the Central Alberta Foothills near Hinton. Papers of Geological Survey of Canada, 84-1B, 263-267.

Kupsch W.O., 1955. Drumlins with jointed boulders near Dollard, Saskatchewan. Geological Society of America Bulletin, 66, 327-338.

Kübler S., 2013. Active tectonics of the Lower Rhine Graben (NW Central Europe) based on new paleoseismological constraints and implications for coseismic rupture processes in unconsolidated gravels. Ludwig-Maximilians-Universität München [Ph.D. thesis].

Kübler S., Friedrich A.M., Gold R.D. \& Strecker M.R., 2018. Historical coseismic surface deformation of fluvial gravel deposits, Schafberg fault, Lower Rhine Graben, Germany. International Journal of Earth Sciences, 107, 571-585.

Little T.A., 1995. Brittle deformation adjacent to the Awatere strike-slip fault in New Zealand: Faulting patterns, scaling relationships, and displacement partitioning. Geological Society of America Bulletin, 107, 1255-1271.

Meyer M.C., Wiesmayr G., Brauner M., Häusler H. \& Wangda D., 2006. Active tectonics in Eastern Lunana (NW Bhutan): Implications for the seismic and glacial hazard potential of the Bhutan Himalaya. Tectonics, 25, 1-21.

Mondal T.K. \& Acharyya S.S., 2018. Fractured micro-granitoid enclaves: A stress marker. Journal of Structural Geology, 113, 33-41, https://doi.org/10.1016/j.jsg.2018.05.011. 
Montes C., Hatcher Jr., R.D. \& Restrepo-Pace A., 2005. Tectonic reconstruction of the northern Andean blocks: oblique convergence and rotations derived from the kinematics of the Piedras-Girardot area, Colombia. Tectonophysics, 399, 221-250.

Nieć M., Mochnacka K. \& Sass-Gustkiewicz M., 2016. Geologia miejsc niezwykłych: Uluru, Kata Tjuta, Kings Canyon w Australii [Geology of the unique places of Uluru, Kata Tjuta and Kings Canyon in Australia]. Przegląd Geologiczny, 64, 5, 299-305.

Phan D.P., Tokarski A.K., Świerczewska A., Strzelecki P.J., Waliczek M., Krąpiec M. \& Cuong N.Q., 2019. Neotectonic (Miocene to recent) vertical movements in the Lao Cai Basin (Red River Fault Zone, Vietnam): An approach to seismic hazard assessment. Journal of Asian EarthSciences, 181,103885, https://doi.org/10.1016/j.jseaes. 2019.103885

Ramsay D.M., 1962. The Highland Boundary Fault: reverse or wrench fault? Nature, 195, 1190-1191.

Ramsay D.M., 1964. Deformation of pebbles in the lower Old Red Sandstone conglomerates adjacent to the Highland Boundary Fault. Geological Magazine, 101, 228-248.

Raymond O.L., Liu S., Gallagher R., Zhang W. \& Highet L.M. 2012. Surface Geology of Australia 1:1 million scale dataset, 2012 edition. Geoscience Australia, Canberra.
Sandiford M., Hand M. \& McLaren S., 2001. Tectonic feedback, intraplate orogeny and the geochemical structure of the crust: a central Australian perspective. [in:] Miller J.A., Holdsworth R.E., Buick I.S. \& Hand M. (eds.), Continental Reactivation and Reworking, Geological Society, London, Special Publications, 184, The Geological Society of London, 195-218.

Tanner W.F., 1976. Tectonically significant pebble types: Sheared, pocked and second-cycle examples. Sedimentary Geology, 16, 69-83.

Tokarski A.K., Márton E., Świerczewska A., Fheed A., Zasadni J. \& Kukulak J., 2016. Neotectonic rotations in the Orava-Nowy Targ Intramontane Basin (Western Carpathians): An integrated palaeomagnetic and fractured clasts study. Tectonophysics, 685, 35-43.

Twidale C.R., 2010. Uluru (Ayers Rock) and Kata Tjuta (The Olgas): Inselbergs of Central Australia. [in:] Migoń P. (ed.), Geomorphological Landscapes of the World, Springer Science+Business Media B.V, 321-332.

Trevelyan W.C., 1845. On fractured boulders found at Auchmithie near Arbroath. Quaternary. Journal of the Geological Society, 1, 147-148.

Young D.N. Duncan N., Camacho A., Ferenczi P.A. \& Madigan T.L.A., 2002. Ayers Rock, Northern Territory Geological Survey ( $2^{\text {nd }}$ ed.). Sheet SG 52-8, 1:250 000. Geological Map Series Explanatory Notes, Darwin. 